\title{
The future of Neurology
}

\section{Building on a strong foundation}

José G. Merino, MD, MPhil

Neurology ${ }^{\circledR}$ 2020;94:599-600. doi:10.1212/WNL.0000000000009265
Correspondence

Dr. Merino

jose.g.merino@

gunet.georgetown.edu

As incoming Editor-in-Chief, I will build on a strong foundation. Under the leadership of Robert A. Gross, MD, PhD, and a dedicated team of editors and editorial staff, Neurology ${ }^{\circledR}$ has become the most influential clinical neurology journal in the world: it receives the most citations and has the highest Eigenfactor score, a measure of the journal's importance to the wider scientific community. It is also the clinical neurology journal with the widest distribution, and articles published in Neurology influence what neurologists do every day. The journal has pioneered editorial practices that promote transparent research reports and mitigate financial and other conflicts of interest. It has implemented new ways to bring its content to readers online, in print, and through podcasts and other social media. Neurology has 3 successful sister journals focused on practice issues and research in highly specialized areas, and these journals complement other American Academy of Neurology (AAN) publications.

Neurology prioritizes research and educational content that is relevant to neurologists at all stages of their careers and in a variety of settings: clinical, research, education, policymaking, and public health. This is the core of who we are as a journal. To remain influential, Neurology must continue to attract the best papers that fit its scope and mission: those that address basic and clinical research that advances our understanding of diseases and conditions of the nervous system. This broad umbrella includes innovative translational research that has the potential to affect patient care as well as clinical trials, observational studies, systematic reviews, and metaanalyses that will shape clinical decisions and public policies and set the stage for subsequent research studies. We will continue to prioritize these studies, and we want to make it easier for authors to send us their best work. The editorial staff and I will work to simplify the manuscript submission system, expedite the editorial decision-making process, and continue to strengthen the peer-review system, with a focus on rigorous methodologic and statistical review that will not only help us make editorial decisions but also ideally help authors improve their manuscripts.

Our readers deserve manuscripts that fully and transparently describe what was planned and done; report the results clearly, honestly, and in sufficient detail to allow replication; and place the findings in context, avoiding spin. We will continue to enforce adherence to the highest standards of transparency and openness, constantly monitoring the journal's consistent use of reporting guidelines, compliance with registration policies, and avoidance of selective reporting and publication bias. Over the coming months, we will review our standards of statistical reporting and explore ways to fully integrate trial registries, data repositories, and preprint servers into the workflow of the journal to help us identify, select, review, and publish the most relevant studies. We will continue to innovate ways to disseminate the research that we publish, including ongoing successful initiatives such as the podcast, infographics, and press releases. We will look for ways to enhance the online version of the journal-the canonical versionthrough continuous publication, more interactive offerings, and thematic groupings, while continuing to innovate how we present research findings in print.

Diversity among the associate editors, the editorial board, peer reviewers, and editorialists is very important for the journal, not only because it can help mitigate unconscious biases in 
editorial decision-making and research reporting, but also because the field and our patients benefit from the perspective of a diverse academic and clinical workforce. Promoting diversity within the journal is one of my priorities. Readers will notice an equal number of women and men in the incoming core editorial team. Together, we will strive for gender parity when inviting new members of the editorial board, peer reviewers, and editorialists, while also looking for a balanced representation of neurologists from diverse racial and ethnic backgrounds. We also want to increase the number of editorial collaborators with the journal.

Neurology, as the journal of the AAN, can provide educational opportunities for neurologists at various points in their career who are interested in editorial activities. We already do this for trainees in the Resident \& Fellow Section, but we will expand our educational offerings for neurologists at other career stages. Bradford Worrall, MD, MSc, will serve as Deputy Editor for Editorial Education and lead these initiatives. This year we appointed 2 assistant editors to our team. They will receive editorial mentorship as they learn about all aspects of the editorial process: initial triage, reviewer selection, review appraisal, and editorial decision. We will also develop educational offerings for editors, board members, and peer reviewers about the competencies of journal editors. We hope to announce other exciting educational initiatives in the near future.

I am looking forward to the opportunity to work with, and learn from, an outstanding team of editors, some of whom have worked with the journal for years, and thus provide a valuable historical perspective, including Olga Ciccarelli, $\mathrm{PhD}$, FRCP, who will serve as Deputy Editor; Anthony Amato, MD; and Bradford Worrall, MD, MSc. Incoming Associate and Assistant Editors include Rebecca C. Burch, MD; Jonathan Graff-Radford, MD; Jennifer Graves, MD,
PhD, MAS; Peter Hedera, MD; Linda A. Hershey, MD, PhD; Barbara C. Jobst, MD; and Reneé Shellhaas, MD, MS. Two senior editors will serve in important advisory roles: David $S$. Knopman, MD, as Scientific Integrity Advisor; and Jonathan Mink, $\mathrm{MD}, \mathrm{PhD}$, as Ombudsman, as many of the editors of different sections of the journal will continue to collaborate with us.

I am grateful to Dr. Robert Gross and the outgoing associate editors for their advice and support during the editorial transition. Over the past few months, I have benefited from his thoughtful advice and opinions on ongoing editorial challenges and controversies and the mechanics of running a weekly journal. He has also shared with me some of his historical perspectives about the journal. The outstanding editorial staff of Neurology, led by Patricia Baskin, MS, have been extremely helpful, and patient with me, as I learn the intricacies of the manuscript processing system. I am honored and excited to lead Neurology in its new phase. As the journal continues to evolve, I hope to hear from readers, authors, and reviewers. Together, we can continue to grow our journal.

\section{Study funding}

No targeted funding reported.

\section{Disclosure}

J.G. Merino receives an honorarium from the AAN as Editorin-Chief of Neurology; until last year, he received salary support from The BMJ for his role as US Research Editor; he received travel support from the Mexican Academy of Neurology and the Mexican Cerebrovascular Disease Association for talks given at several of their annual meetings; and he was an outcome adjudicator for the Women's Health Initiative between 2009 and 2019 and received an honorarium per adjudicated case. 


\section{Neurology}

The future of Neurology ${ }^{\circledR}$ : Building on a strong foundation

José G. Merino

Neurology 2020;94;599-600 Published Online before print April 1, 2020

DOI 10.1212/WNL.0000000000009265

This information is current as of April 1, 2020

$\begin{array}{ll}\begin{array}{l}\text { Updated Information \& } \\ \text { Services }\end{array} & \begin{array}{l}\text { including high resolution figures, can be found at: } \\ \text { http://n.neurology.org/content/94/14/599.full }\end{array} \\ \text { Permissions \& Licensing } & \begin{array}{l}\text { Information about reproducing this article in parts (figures,tables) or in } \\ \text { its entirety can be found online at: } \\ \text { http://www.neurology.org/about/about_the_journal\#permissions }\end{array} \\ & \begin{array}{l}\text { Information about ordering reprints can be found online: } \\ \text { http://n.neurology.org/subscribers/advertise }\end{array}\end{array}$

Neurology ${ }^{\circledR}$ is the official journal of the American Academy of Neurology. Published continuously since 1951, it is now a weekly with 48 issues per year. Copyright () 2020 American Academy of Neurology. All rights reserved. Print ISSN: 0028-3878. Online ISSN: 1526-632X.

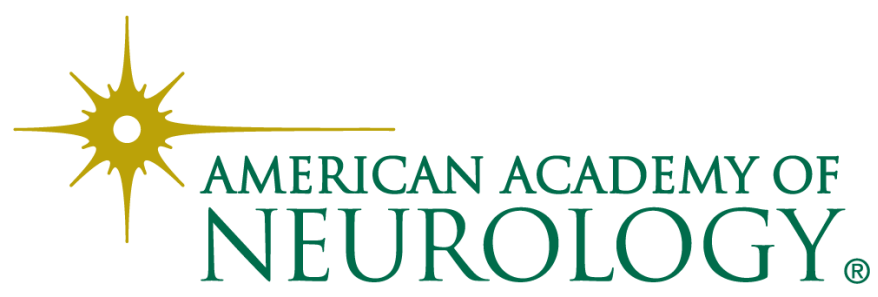

